\title{
Effect Analysis of the Service Quality on Customer Satisfaction at PT. Bee Trans world Logistics Surabaya
}

\author{
Andira Puspita Fajarini \\ Narotama University Indonesia \\ andirapuspitaa@gmail.com
}

\begin{abstract}
PT. Bee Logistics Transworld has service quality that each variable can influence customer satisfaction such as Tangible, Reliability, Responsiveness, Assurance and Empathy. This study aims to determine the effect of Service Quality on Customer Satisfaction. The population of this research is customers of PT. Bee Transworld Logistics Surabaya. Samples of 100 respondents were taken using purposive sampling technique and methods of data collection using questionnaires. Analysis of the data used is multiple linear regression analysis. The results of this study indicate that the Tangible variable (physical evidence) significantly influences the variable customer satisfaction. While the Reliability, Responsiveness, Assurance, and Empathy variables do not significantly influence the customer satisfaction variable.

Keywords: Tangible, Reliability, Responsiveness, Assurance, Empathy.
\end{abstract}

\section{INTRODUCTION}

In the era of 1990, the growing number of freight forwarder services companies, namely, businesses in the field of export and import freight services. Freight forwarders are the key intermediaries involved in the transportation of goods from the origin to the destination by sea or air.

Freight forwarders are third parties in the process of sending exported or imported goods, therefore, forwarders have cooperation with shipping and freight forwarders (exporters) or consignees (importers) besides that, freight forwarding also has full responsibility during the shipping process. Companies that offer services to other parties that can meet consumer needs but are intangible but have interactions between service providers, the production process is not associated with a physical product and does not result in ownership of something is the definition of a service company. It is a characteristic of a service and these characteristics distinguish between products and services

Services and prices offered by freight forwarders must be balanced so that the company can meet consumer needs and consumer expectations because freight forwarders are companies engaged in services. So that the company can achieve loyalty from customers who will later use the services of the company again for the next and so on.

Table 1. Sales Data of PT. Bee Transworld Logistics Surabaya in 2018

\begin{tabular}{llll}
\hline Month & Customer Number & Job Number & Gross profit \\
\hline January & 8 & 75 & $547.465 .683,36$ \\
February & 9 & 46 & $424.812 .866,79$ \\
March & 8 & 65 & $559.031 .298,25$ \\
\hline
\end{tabular}

Based on the background above, the author makes service users of PT. BEE LOGISTICS TRANSWORLD in Surabaya which is a freight forwarder company as a thesis material entitled " Effect Analysis of the Service Quality on Customer Satisfaction at PT. Bee Transworld Logistics Surabaya ".

\section{BASIC THEORY}

\subsection{Service Definition}

Services are defined as actions that can be offered by a party to another party which is essentially intangible (non-physical) and does not result in ownership of something [1]. 
Services have several characteristics that are generally distinguished or classified in 4 characteristics, namely [2]:

a. Intangibility

Services are different from goods. If the goods can be owned. Services are intangibility / cannot be seen, felt, smelled, heard, or touched before being bought and consumed. Thus, people cannot judge the quality of these services before they feel / consume them themselves.

b. Inseparability

Services that are inseparability means that in marketing interaction services between service providers and customers is a special feature in service marketing, both of which affect the results of these services.

c. Variability

Services are variable because they are standardized output, meaning that there are many variations in form, quality and type, depending on who, when, and where the service is produced.

d. Perishability

Services are commodities that are not durable and cannot be stored. Thus if the service is not used, then the service will just go away.

Moreover, 3 characteristics of services, namely [3]:

1. More intangible than tangible.

2. Silmultaneous production and consumption

3. less standarized and uniform

Based on the description of service characteristics described by experts, it can be seen the main characteristics of services are: services are invisible, inseparable, not durable, and variable.

\subsection{Service Quality Measurement}

There are several measurements of service quality, i.e [4]:

1. (reliability), the company's ability to provide services as promised in an accurate and reliable manner. Performance must be in accordance with customer expectations which means timeliness, same service for all customers without errors, sympathetic attitudes, and with high accuracy.

2. (assurance), knowledge, politeness, and the ability of company employees to foster customer trust in the company. Consists of several components including communication (communication), credibility (credibility), security (security), competence (competence), and courtesy (courtesy).

3. (tangible), the ability of a company to show its existence to external parties. The appearance and capabilities of the company's physical facilities and infrastructure and the state of the surrounding environment are concrete evidence of services provided by service providers, which include physical facilities (buildings, warehouses, etc.), equipment and equipment used (technology), and the appearance of the employees.

4. (empathy), give sincere and individual or personal attention given to customers by trying to understand consumer desires. Where a company is expected to have understanding and knowledge of customers, understand customer needs specifically, and have a comfortable operating time for customers.

5. (responsiveness), willingness to help and provide fast and appropriate service to customers, with the delivery of clear information. Allowing consumers to wait without a clear reason causes a negative perception of service quality. One factor that determines the level of success and quality of the company is the company's ability to provide services to customers.

\subsection{Customer satisfaction}

Customer satisfaction has been a central concept in marketing literature and is an important goal of all business activities. Today, companies face their toughest competition, because they move from a product and sales philosophy to a marketing philosophy, which gives a company a better chance of outperforming competition [5]. 


\section{CONCEPTUAL FRAMEWORK}

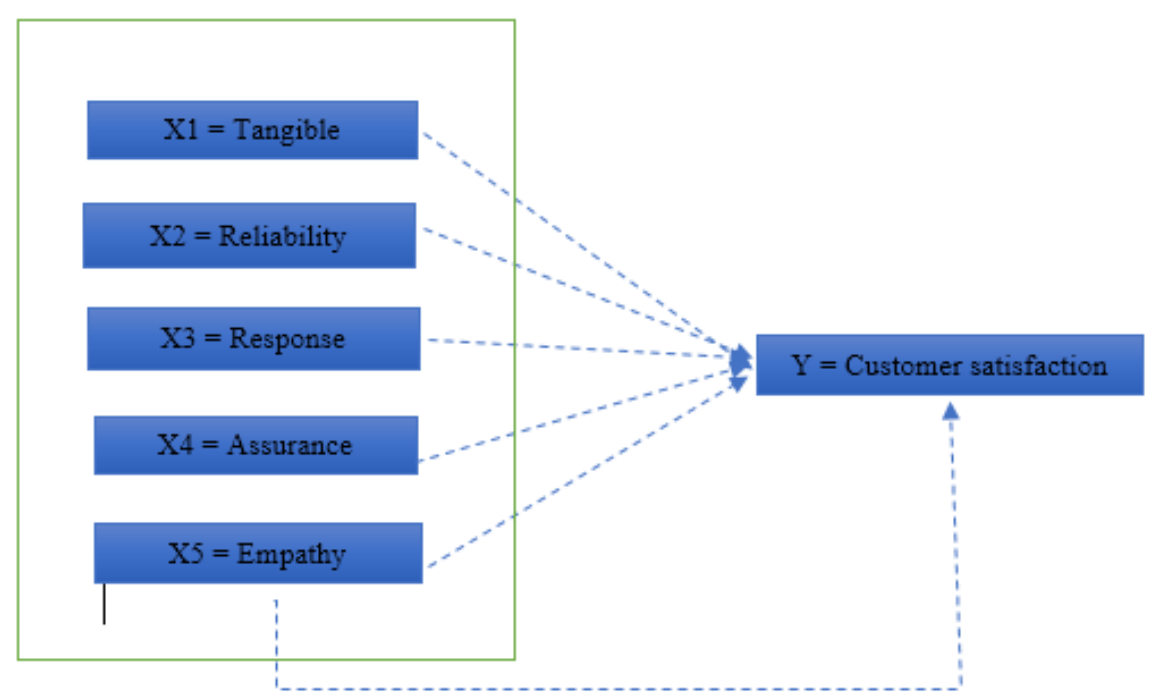

Fig. 1. Conceptual Framework

\section{HYPHOTHESIS}

Based on the background of the problem and the formulation of the problem as mentioned above regarding the research, the following hypothesis is proposed:

H1 : There are variables such as Tangibles, Reliability, Responsiveness, Assurance, and Empathy that have a simultaneous effect on customer satisfaction at PT. Bee Transworld Logistics Surabaya

$\mathrm{H} 2$ : There is a variable Tangibles partially influencing customer satisfaction at PT. Bee Transworld Logistics Surabaya

H3 : There is a variable Reliability partially affects customer satisfaction PT. Bee Transworld Logistics Surabaya

$\mathrm{H} 4$ : There is a responsiveness variable that has a partial effect on customer satisfaction at PT. Bee Transworld Logistics Surabaya

H5: There is variable Assurance partially influencing customer satisfaction PT. Bee Transworld Logistics Surabaya

H6 : There is an empathy variable that has partial effect on customer satisfaction at PT. Bee Transworld Logistics Surabaya

\section{RESEARCH METHOD}

This study uses a purposive sampling technique and the method of collecting data using questionnaires.The population of this research is customers of PT. Bee Transworld Logistics Surabaya and took a sample of 100 respondents. Analysis of the data used is multiple linear regression analysis.

\subsection{Analysis of Reliability and Validity}

1. Reliability test

Basic measurement decision making reliability test that will be used in this study is using version 16 of the SPSS analysis tool (Statistical Package for Social Science), that is, with the Cronbach Alpha statistical test. A construct or variable is declared reliable if the cronbach alpha value is> 0.60 [6].

2. Validity Test 
Decision making to measure validity can be done by making a correlation between the scores of questions with a total score construct or variable. That is by comparing the value of $r$ count with $r$ table for the degree of freedom $(\mathrm{df})=\mathrm{n}-2$, where $(\mathrm{n})$ is the number of research samples. If $\mathrm{r}$ count $>\mathrm{r}$ table and the value is positive then the item or question or indicator is declared valid.

\subsection{Analysis of Multiple Linear Regression}

The multiple linear regression equation model is as follows:

$$
\mathrm{Y}=\mathrm{b} 1 \mathrm{X} 1+\mathrm{b} 2 \mathrm{X} 2+\mathrm{b3} \mathbf{X 3}+\mathrm{e}
$$

Where:

$\begin{array}{ll}\text { Y } & \text { : Customer loyalty } \\ \text { b1, b2, b3 } & \text { : Regression coefficient } \\ \text { X1 } & \text { : Product quality } \\ \text { X2 } & \text { : Service quality } \\ \text { X3 } & \text { : Customer trust } \\ \text { e } & \text { : error }\end{array}$

\subsection{Hypothesis Analysis}

1. Determination Coefficient Test $R^{2}$

2. Simultaneous Test (F)

3. Partial Test (T-Test)

\section{RESULTS AND DISCUSSION}

\subsection{Reliability and Validity Test Results}

1. Reliability Test

The following are the outputs of the reliability test through the SPSS 23 program which can be seen in the following table :

Table 2. Reliability Test

\begin{tabular}{lllll}
\hline \multicolumn{2}{l}{ Item-Total Statistics } & & & \\
& $\begin{array}{l}\text { Scale Mean if } \\
\text { Item Deleted }\end{array}$ & $\begin{array}{l}\text { Scale } \\
\text { Variance } \\
\text { Item Deleted }\end{array}$ & $\begin{array}{l}\text { if } \\
\text { Corrected } \\
\text { Item-Total } \\
\text { Correlation }\end{array}$ & $\begin{array}{l}\text { Cronbach's } \\
\text { Alpha if Item } \\
\text { Deleted }\end{array}$ \\
\hline $\mathbf{X 1 . 1}$ & 54.6107 & 199.861 & .818 & .976 \\
$\mathbf{X 1 . 2}$ & 54.6705 & 198.116 & .863 & .975 \\
$\mathbf{X 1 . 3}$ & 54.7245 & 198.282 & .849 & .975 \\
$\mathbf{X 2 . 1}$ & 54.2608 & 198.327 & .867 & .975 \\
$\mathbf{X 2 . 2}$ & 54.6107 & 198.737 & .828 & .975 \\
$\mathbf{X 2 . 3}$ & 54.4661 & 197.479 & .889 & .975 \\
$\mathbf{X 3 . 1}$ & 54.5435 & 199.101 & .852 & .975 \\
$\mathbf{X 3 . 2}$ & 54.3745 & 200.512 & .803 & .976 \\
$\mathbf{X 3 . 3}$ & 54.6107 & 200.417 & .768 & .976 \\
$\mathbf{X 4 . 1}$ & 54.3745 & 204.775 & .628 & .977 \\
$\mathbf{X 4 . 2}$ & 54.3745 & 200.712 & .787 & .976 \\
$\mathbf{X 4 . 3}$ & 54.7245 & 198.352 & .854 & .975 \\
$\mathbf{X 5 . 1}$ & 54.7245 & 197.280 & .884 & .975 \\
$\mathbf{X 5 . 2}$ & 54.2608 & 198.744 & .833 & .975 \\
$\mathbf{X 5 . 3}$ & 54.5435 & 199.336 & .822 & .976 \\
Y1.1 & 54.2608 & 197.152 & .909 & .975 \\
$\mathbf{Y 1 . 2}$ & 54.5435 & 199.256 & .844 & .975 \\
Y1.3 & 54.4661 & 198.768 & .851 & .975 \\
Y1.4 & 54.3745 & 204.775 & .628 & .977 \\
\hline
\end{tabular}


2. Validity Test

Table 3. Validity Test

$\begin{array}{lccc}\text { Statement item } & \boldsymbol{r}_{\text {count }} & \boldsymbol{r}_{\text {tabel }} & \text { Information } \\ \text { Tangibles (X1) } & & & \\ \text { X1.1 } & 0,818 & 0,1654 & \text { Valid } \\ \text { X1.2 } & 0,863 & 0,1654 & \text { Valid } \\ \text { X1.3 } & 0,849 & 0,1654 & \text { Valid } \\ \text { Reliability (X2) } & & & \\ \text { X2.1 } & 0,867 & 0,1654 & \text { Valid } \\ \text { X2.2 } & 0,828 & 0,1654 & \text { Valid } \\ \text { X2.3 } & 0,889 & 0,1654 & \text { Valid } \\ \text { Responsiveness (X3) } & & & \\ \text { X3.1 } & 0,852 & 0,1654 & \text { Valid } \\ \text { X3.2 } & 0,803 & 0,1654 & \text { Valid } \\ \text { X3.3 } & 0,768 & 0,1654 & \text { Valid } \\ \text { Assurance (X4) } & & & \\ \text { X4.1 } & 0,628 & 0,1654 & \text { Valid } \\ \text { X4.2 } & 0,787 & 0,1654 & \text { Valid } \\ \text { X4.3 } & 0,854 & 0,1654 & \text { Valid } \\ \text { Empathy (X5) } & & & \\ \text { X5.1 } & 0,884 & 0,1654 & \text { Valid } \\ \text { X5.2 } & 0,833 & 0,1654 & \text { Valid } \\ \text { X5.3 } & 0,822 & 0,1654 & \text { Valid } \\ \text { Customer satisfaction } & & & \\ \text { (Y1) } & & & \\ & & & \\ \text { Y1.1 } & 0,909 & 0,1654 & \text { Valid } \\ \text { Y1.2 } & 0,844 & 0,1654 & \text { Valid } \\ \text { Y1.3 } & 0,851 & 0,1654 & \text { Valid } \\ \text { Y1.4 } & 0,628 & 0,1654 & \text { Valid }\end{array}$

From the data above, states that 19 items of statements given to 100 respondents found the value of Corrected Item-Total Correlation is greater than the value of $r_{-}$tabel $(0.1654)$ which means the data is valid.

\subsection{Results of Multiple Linear Regression Analysis}

Table 4. Multiple Linear Regression Analysis

\begin{tabular}{|c|c|c|c|c|c|c|}
\hline \multicolumn{7}{|c|}{ Coefficients $^{\mathrm{a}}$} \\
\hline \multirow{2}{*}{\multicolumn{2}{|c|}{ Model }} & \multicolumn{2}{|c|}{ Unstandardized Coefficients } & \multicolumn{3}{|c|}{$\begin{array}{l}\text { Standardized } \\
\text { Coefficients }\end{array}$} \\
\hline & & $\mathrm{B}$ & Std. Error & Beta & $\mathrm{t}$ & Sig. \\
\hline \multirow[t]{6}{*}{1} & (Constant) & 1.855 & .719 & & 2.579 & .011 \\
\hline & $\mathrm{X} 1$ & .235 & .104 & .232 & 2.258 & .026 \\
\hline & $\mathrm{X} 2$ & -.040 & .102 & -.039 & -.398 & 692 \\
\hline & $\mathrm{X} 3$ & .111 & .088 & .126 & 1.252 & .214 \\
\hline & $\mathrm{X} 4$ & .150 & .091 & .163 & 1.656 & .101 \\
\hline & $\mathrm{X} 5$ & .022 & .084 & .026 & .261 & .794 \\
\hline \multicolumn{7}{|c|}{ a. Dependent Variable: Y1 } \\
\hline
\end{tabular}




\section{HYPOTHESIS TEST RESULTS}

\subsection{Determination Coefficient Test $\boldsymbol{R}^{2}$}

Table 5. Coefficient Test $R^{2}$

Model Summary

\begin{tabular}{llllll}
\hline & & & & Std. Error of the \\
Model & $\mathrm{R}$ & R Square & Adjusted R Square & Estimate & \\
\hline 1 & $.989^{\mathrm{a}}$ & .978 & .977 & .14597
\end{tabular}

a. Predictors: (Constant), X5, X2, X4, X1, X3

b. Dependent Variable: Y

From the results of the table above, it can be seen that the determination coefficient is 0.977 and the adjusted $\mathrm{R}$ square is 0.977 . This means that $97 \%$ of customer satisfaction can be explained by tangibles, reliability, responsiveness, assurance and empathy variables, while the remaining 3\% customer satisfaction is influenced by other variables not inspected in this study.

\subsection{Simultaneous Test (F)}

Table 6. Simultaneous Test (F)

\begin{tabular}{lllllll} 
ANOVA $^{\mathbf{a}}$ & \multicolumn{1}{l}{} \\
\hline Model & & Sum of Squares & df & Mean Square & F & Sig. \\
\hline 1 & Regression & 90.282 & 5 & 18.056 & 847.433 & $.000^{\mathrm{b}}$ \\
& Residual & 2.003 & 94 & .021 & & \\
& Total & 92.285 & 99 & & & \\
\hline
\end{tabular}

a. Dependent Variable: Y

b. Predictors: (Constant), X5, X2, X4, X1, X3

From the Anova table, the F test produces an F-count of 847.433 with a probability value (sig) of 0,000 , and F-table of 2,31 with a significant value of 0.05 . Because the calculated $F$ value is greater than F-table $(847.433>2.31)$ then reject Ho and accept Ha. So it can be concluded that there is a positive and significant influence between Tangibles (X1), Reliability (X2), Responsiveness (X3), Assurance (X4), and Empathy (X5) together towards Customer Satisfaction (Y).

\section{PARTIAL TEST (T-Test)}

Table 7. Partial Test (T-Test)

\begin{tabular}{|c|c|c|c|c|c|c|}
\hline \multicolumn{7}{|c|}{ Coefficients $^{a}$} \\
\hline \multirow{2}{*}{\multicolumn{2}{|c|}{ Model }} & \multicolumn{2}{|c|}{ Unstandardized Coefficients } & \multicolumn{3}{|c|}{$\begin{array}{l}\text { Standardized } \\
\text { Coefficients }\end{array}$} \\
\hline & & B & Std. Error & Beta & $\mathrm{t}$ & Sig. \\
\hline \multirow[t]{6}{*}{1} & (Constant) & 1.855 & .719 & & 2.579 & .011 \\
\hline & $\mathrm{X} 1$ & .235 & .104 & .232 & 2.258 & .026 \\
\hline & $\mathrm{X} 2$ & -.040 & .102 & -.039 & -.398 & .692 \\
\hline & $\mathrm{X} 3$ & .111 & .088 & .126 & 1.252 & .214 \\
\hline & $\mathrm{X} 4$ & .150 & .091 & .163 & 1.656 & .101 \\
\hline & $\mathrm{X} 5$ & .022 & .084 & .026 & .261 & .794 \\
\hline
\end{tabular}

8.1 Partial Test Between Variable Tangibles (X1) Against Variable Customer Satisfaction (Y)

To test the hypothesis used the t test which shows the partial effect of the Tangibles variable (X1) on the Customer Satisfaction variable (Y).

Based on SPSS 23 output obtained t_count (2.258) <from t_table (1.985) then H2 is accepted. So that it can be concluded that partially the Tangibles variable (X1) has a significant effect on Customer Satisfaction (Y). 
8.2 Partial Test Between Reliability Variables (X2) Against Variable Customer Satisfaction (Y) To test the hypothesis the t-test is used which shows the influence partially Reliability variable (X1) on the Customer Satisfaction variable (Y). Based on SPSS 23 output obtained t_count $(-398)<$ from t_table $(1,985)$ then H3 is rejected. So, it can be concluded that the variable Reliability (X2) partially does not have a significant effect on Customer Satisfaction (Y).

\subsection{Partial Test Between Responsiveness Variables (X3) Towards Customer Satisfaction Variables} (Y)

To test the hypothesis, the t-test is used which shows the effect partially of the Responsiveness variable (X3) on the Customer Satisfaction variable (Y). Based on SPSS 23 output obtained t_count $(1.252)<$ from t_table (1.985) then $\mathrm{H} 4$ is rejected. So that it can be concluded that partially the Responsiveness variable (X3) does not have a significant effect on Customer Satisfaction (Y).

\subsection{Partial Test Between Variable Assurance (X4) Against Variable Customer Satisfaction (Y)}

To test the hypothesis, the t-test will be used which shows the partial effect of Assurance variable (X4) on the Customer Satisfaction variable (Y). Based on SPSS 23 output obtained t_count $(1.656)<$ from t_table $(1,985)$ then H5 is rejected. It can be concluded that partially Assurance variable (X4) has no significant effect on Customer Satisfaction (Y).

\subsection{Partial Test Between Empathy Variables (X5) Against Variable Customer Satisfaction (Y)}

To test the hypothesis, the t-test will be used which shows the partial effect of the Empathy variable (X5) on the value of Customer Satisfaction (Y). Based on the output of SPSS 23 obtained $t$ _count $(0.261)<$ from $t$ table $(1.985)$ then H6 is rejected. So, it can be concluded that the Empathy variable (X5) partially does not have a significant effect on Customer Satisfaction (Y).

\section{CONCLUSIONS AND RECOMMENDATIONS}

\subsection{Conclusions}

1. Based on the results of the study, the following multiple linear regression equations will be obtained: $\mathrm{Y}=1,855+0,235 \mathrm{X} 1+-0,40 \mathrm{X} 2+0,111 \mathrm{X} 3+0,150 \mathrm{X} 4+0,022 \mathrm{X} 5+0,289$

2. Based on the results of multiple linear regression analysis, it can be seen that the most influential variable on customer satisfaction is the X2 Reliability variable with a regression coefficient of 0.4 (40 percent).

3. Coefficient of determination $R^{2}$ is 0.977 . This means that $97 \%$ of customer satisfaction can be explained by tangible, reliability, responsiveness, assurance, empathy variables, while the remaining $3 \%$ customer satisfaction is influenced by other variables not inspected in this study.

4. In hypothesis testing using the $F$ test (together or simultaneously it can be explained that the five variables are tangible (X1), reliability (X2), responsiveness (X3), assurance (X4), empathy (X5) on the dependent variable of customer satisfaction ( $\mathrm{Y}$ ) jointly influences customer satisfaction, this is indicated by the F-count value of 17.947 with probability values (sig) 0.000 and F-table of 2.31 with a significant value of 0.05 ..

5. The results of the $T$ test (partial test) show partially the Tangible variable (X1) has a significant effect on Customer Satisfaction (Y), while the Reliability variable (X2), Responsiveness (X3), Assurance (X4), and Empathy (X5) have no significant effect towards Customer Satisfaction (Y).

\subsection{Recommendations}

1. It is expected that the company can maintain and increase reliability (reliability) because it has a large influence on customer satisfaction PT. Transworld Bee Logistics.

2. Given that the independent variables in this study are very important, it is expected that the results of this study can be used as a reference for future researchers to develop this research by considering other variables. 


\section{REFERENCE}

[1] K. L. Kotler, P., \& Keller, Manajemen Pemasaran Edisi 12. Jakarta: Indeks, 2007.

[2] P. Kotler, Manajemen Pemasaran Alih bahasa: Hendra Teguh, Ronny Antonius Rusli Jilid I. Jakarta: PT. Prenhalindo, 2002.

[3] B. Alma, Manajemen Pemasaran Dan Pemasaran Jasa. Bandung: Alfabeta, 2011.

[4] J. Lovelock, C., \& Wirtz, Manajemen Pemasaran Jasa (Terjemahan). Jakarta: PT. Indeks, 2005.

[5] P. Kotler, Marketing Management. New Jersey: Prentice-Hall, 2000.

[6] I. Ghozali, Aplikasi Analisis Multivariate dengan program SPSS. Semarang: Universitas Diponegoro., 2006. 